\title{
Distribution and toxicity of Cylindrospermopsis raciborskii (Cyanobacteria) in Portuguese freshwaters
}

\author{
Martin L. Saker ${ }^{*}$, Isabel C. G. Nogueira ${ }^{1}$ and Vitor M. Vasconcelos ${ }^{1}$ \\ ${ }^{1}$ Departamento de Zoologia e Antropologia, Faculdade de Ciências, Praça Gomes Teixeira, Porto 4050 \\ Portugal and Centro Interdisciplinar de Investigação Marinha e Ambiental, Rua dos Bragas 177, 4050 \\ Porto, Portugal. \\ *Departmento de Zoologia e Antropologia. Faculdade de Ciências. Praça Gomes Teixeira. 4050 Porto. \\ Portugal. Phone: +351 22 3401813. Fax:+351 22 3390608. Email: msaker@fc.up.pt
}

\begin{abstract}
The cyanobacterium Cylindrospermopsis racborskii has become increasingly prevalent in freshwaters worldwide. This species is of concern from a water quality perspective due to its known ability to produce a potent hepatotoxic alkaloid cylindrospermopsin, which has been implicated in outbreaks of human sickness and cattle mortality. C. raciborskii isolates from Brazil have also been found to produce the highly toxic paralytic shellfish poisons (PSP's). In this paper we report the toxicity of four isolates of $C$. raciborskii taken from three reservoirs and one river in Portugal as well as the occurrence of this species in other water bodies used for potable and recreational purposes. All four isolates grown in pure culture in the laboratory were found to be toxic in the mouse bioassay at $8-24$ hours after intraperitoneal administration of single doses ranging from 1337 to $1572 \mathrm{mg} \mathrm{kg}^{-1}$. Histological examination showed liver damage as the primary lesion, in addition to some inflammation in the intestine. HPLC/MS tests for the presence of cylindrospermopsin, microcystins and PSP toxins were negative. The available evidence suggests that another toxin may be present. This report constitutes the first report of toxic C. raciborskii in Europe and draws attention to our need for increased monitoring of this cyanobacterium in water bodies used for potable and recreational purposes.
\end{abstract}

Keywords: Cyanobacteria, Cylindrospermopsis, freshwaters, toxicity, Portugal

\section{RESUMEN}

La cianobacteria Cylindrospermopsis racborskii ha incrementado su presencia en agua dulce por todo el mundo. Esta especie es de gran importancia debido a su conocida capacidad para producir un alcaloide hepatotóxico, cilindrospermopsina. Esta toxina es responsable de enfermedades en humanos y mortalidad en ganado. Cepas de C. raciborskii aisladas de Brasil se ha demostrado que tienen capacidad para producir la toxina paralytic shellfish poisons (PSP's). En este trabajo hemos estudiado la presencia de esta especie en agua dulce con usos recreacionales y de abastecimiento en Portugal. De las cuatro cepas $\mathrm{C}$. raciborskii aisladas de tres embalses y de un río estudiamos la toxicidad con bioensayos en ratones. Todas presentaron toxicidad al cabo de las 8-24 horas tras inyección intraperitoneal, la dosis presenta un rango de concentración de 1337 a $1572 \mathrm{mg}$ $\mathrm{kg}^{-1}$. La examinación histológica reveló daños en el hígado y señales inflamatorias en el intestino. Los análisis con HPLC/MS revelaron la ausencia de cilindrospermopsina, microcistinas y PSP, sugiriendo que otra toxina podría estar presente para las cepas aisladas y cultivadas en laboratorio. Este artículo es el primero acerca de la toxicidad de C. raciborskii en Europa y refleja la necesidad de aumentar el monitoreo de esta cyanobacteria en el agua potable y con fines recreativos.

Palabras clave: Cianobacteria, Cylindrospermopsis, aguas continentasles, toxicidad, Portugal

\section{INTRODUCTION}

The freshwater, planktonic cyanobacterium Cylindrospermopsis raciborskii (Order Nostocales) was originally described as a species of only tropical interest (Woloszynska, 1912). A recent review of the worldwide occurrence of C. raciborskii by Padisák (1997) highlighted the increasing number of reports of this species from many temperate European countries including Austria (Dokulil \& Mayer, 1996), France (Briand et al., -In press; Couté et al., 1997), Germany 
(Krienitz \& Hegewald, 1996), Greece (Hindák \& Moustaka, 1988), Hungary (Padisák, 1997), Spain (Romo \& Miracle, 1994) and Slovakia (Horecká \& Komárek, 1979).

This species is of concern from a water quality perspective due to its ability to produce toxic compounds that can potentially affect the health of humans and other animals. The tricyclic alkaloid cylindrospermopsin has been reported to be produced by $C$. raciborskii strains from Australia (Hawkins et al., 1997; Saker et al., 1999a,b; Saker \& Griffiths, 2000) and Thailand (Li et al., 2001). This compound causes severe liver damage in the mouse bioassay (Hawkins et al., 1985; Hawkins et al., 1997; Ohtani et al., 1992) with symptoms clearly distinguishable from those of some other cyanobacterial hepatotoxins including nodularin and microcystin. Cylindrospermopsin has been implicated in outbreaks of human sickness (Bourke et al., 1983; Byth, 1980) and cattle mortality (Saker et al., 1999b; Thomas et al., 1998) and in recognition of its potency, a water quality guideline value of $1 \mu \mathrm{g} \mathrm{L}^{-1}$ has been proposed (Shaw et al., 2000). Paralytic shellfish poisons (PSP's) including neosaxitoxin, saxitoxin and gonyautoxin $2 / 3$ isomers, similar to those produced by another freshwater cyanobacterium Anabaena circinalis, have also been detected in isolates of $C$. raciborskii from Brazil (Lagos et al., 1999). These toxins have been implicated in the death of humans and other animals (Ressom et al., 1994).

In this paper, we investigate the distribution of $C$. raciborskii in a range of Portuguese freshwaters and report on the toxicity of four isolates of $C$. raciborskii taken from one river and three reservoirs in Portugal and grown in pure culture. The toxicity of these isolates has been investigated by mouse bioassay (intraperitoneal (i.p) administration) and by HPLC/MS.

\section{METHODS}

\section{Isolation and culture of $\boldsymbol{C}$. raciborskii}

Cylindrospermopsis raciborskii (Woloszyńska) Seenayya and Subba Raju isolates, identified using the taxonomic descriptions of Baker (1991) and Komárek \& Kling (1991) were taken from three reservoirs (Odivelas Reservoir, Caia Reservoir and Maranhão Reservoir) and one river (Ardila River) in the south of Portugal between July to October 1999. The location of the four source water bodies are shown in figure 1 .

Isolation into pure culture was by transference of single trichomes as previously described (Saker et al., 1999a) into sterile plastic $10 \mathrm{ml}$ centrifuge tubes containing $5 \mathrm{ml}$ of Z8 media (Kotai, 1972) modified by the omission of all combined forms of nitrogen. Cultures were maintained at $20 \pm 1^{\circ} \mathrm{C}$ and incident light intensity of $10 \mu \mathrm{mol} \mathrm{m}{ }^{-2} \mathrm{~s}^{-1}$ provided by cool white fluorescent tubes (14:10; light:dark cycle).

Cultures in the late exponential growth phase $(100 \mathrm{ml})$ were used to inoculate $6 \mathrm{~L}$ culture flasks containing $4 \mathrm{~L}$ of nitrogen replete $\mathrm{Z} 8$ medium. The flasks were incubated under the conditions described above and at the end of the exponential growth phase, these cultures were harvested by gravity filtration onto GF/C filter paper, frozen and freeze dried.

$50 \mathrm{ml}$ sub-samples of the C. raciborskii cultures were preserved with Lugols' solution for morphological measurement of vegetative cells and heterocysts, using a Leica DM LB image analysis system. For each of the morphological variables, $>30$ measurements were taken. End cells were excluded from the analysis due to the greater variability in end cell shape (Singh, 1962).

\section{Mouse bioassay}

Freeze dried biomass (ca. $145-160 \mathrm{mg}$ ) from the four $C$. raciborskii isolates was sonicated in $5 \mathrm{ml}$ of physiological saline, on ice, at $50 \mathrm{~Hz}$ for five minutes. Sonicated cell suspensions were inspected microscopically (to ensure complete cell lysis) and $1 \mathrm{ml}$ administered intra-peritoneally to each of two white male Charles River mice $(23-25 \mathrm{~g}$ weight). Two control animals were dosed with $1 \mathrm{ml}$ of physiological saline and another two mice with $1 \mathrm{ml}$ of a sonicated cell suspension of Ankistrodesmus falcatus (Corda) Ralfs in physiological saline. All mice were observed regularly. 


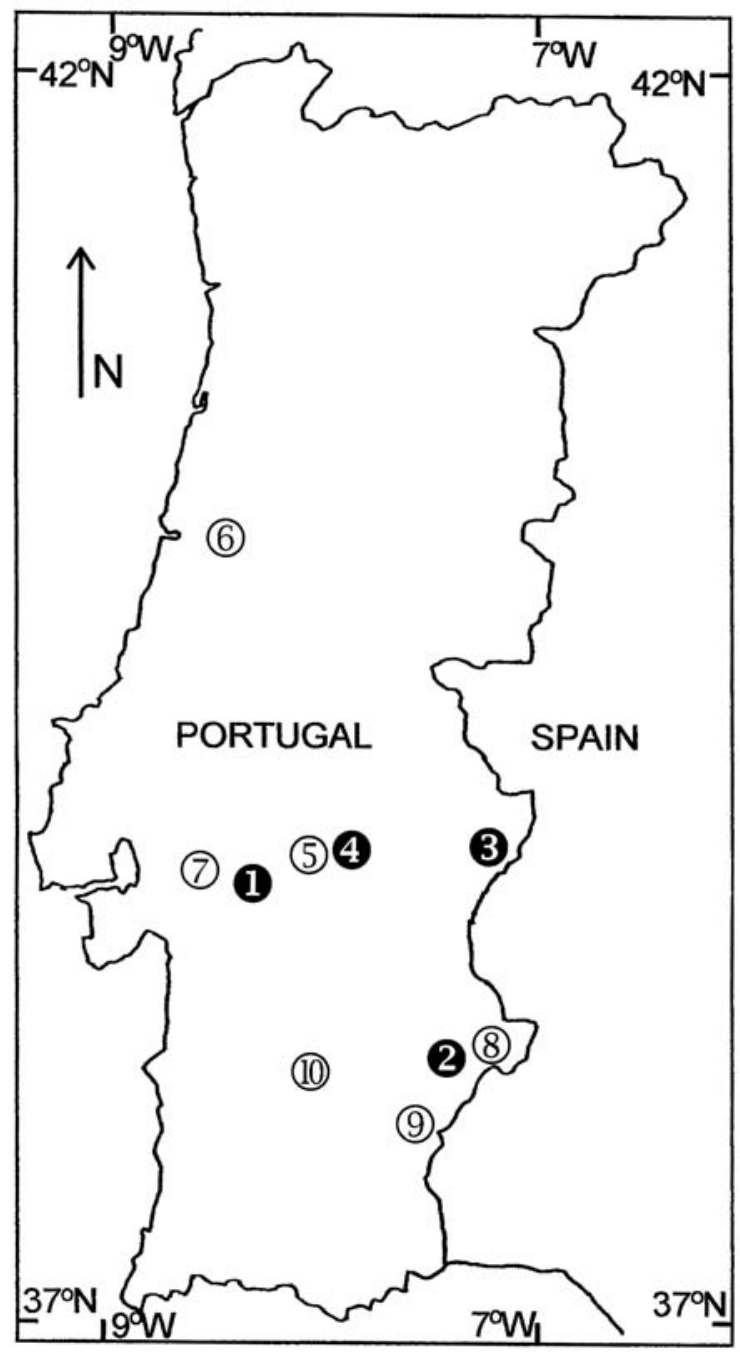

Figure 1. Map of Portugal showing the four sites from which C. raciborskii has been isolated in this study (closed circles) as well as other sites where this species is seasonally abundant as a component of the phytoplankton (open circles). The sites are as follows; (1) Odivelas Reservoir (PT1), (2) Ardila River (PT2), (3) Caia Reservoir (PT3), (4) Maranhão Reservoir (PT4), (5) Montargil Reservoir, (6) Velas Lagoon, (7) Agolada Reservoir, (8) Bufo Reservoir, (9) Mertola Reservoir, (10) Patudos Reservoir. Mapa de Portugal mostrando las cuatro localidades en las que C. raciborskii ha sido aislada para este estudio (círculos negros) asi como otras localidades en las que esta especia es estacionalmente abundante como componente del fitoplancton (círculos blancos). Las localidades son: (1) embalse de Odivelas (PT1), (2) río Ardila (PT2), (3) embalse de Caia (PT3), (4) embalse de Maranhão (PT4), (5) embalse de Montargil, (6) laguna de Velas, (7) embalse de Agolada, (8) embalse de Bufo, (9) embalse de Mertola, (10) embalse de Patudos.
Moribund mice were necropsied by cervical dislocation. Portions of cecum, liver, lung, kidney and upper and lower intestine were immediately removed, washed with Dulbecco's buffered saline (Sigma), fixed in Boiun fixative (Sigma), and included in paraffin. Sections $(5-7 \mu \mathrm{m})$ were stained with haematoxilin and eosin and analysed with a HP Leica DMLB optical microscope with and 100x, 400x and 1000x magnification.

\section{HPLC analysis of toxins}

For the analysis of microcystins, lyophilised $C$. raciborskii samples were sonicated in $20 \%$ methanol, filtered $(0.2 \mu \mathrm{m})$ and analysed using a Shimadzu LC6-AD HPLC system equipped with a Shimadzu SPD-M10A diode array detector. An Altima C18 column (150mm x $4.6 \mathrm{~mm}$, $5 \mu \mathrm{m})$ was used with a $1 \mathrm{~mL}$ per minute linear gradient of $15 \%$ to $45 \%$ methanol / $8 \mathrm{mM}$ Ammonium acetate in 30 mins. Microcystins if present were identified by their characteristic UV spectrum and quantified by comparison to a microcystin-LR standard (Calbiochem \# B28160). The detection limits using this technique were generally less than $0.5 \mu \mathrm{g} \mathrm{L}^{-1}$.

For the analysis of saxitoxins, lyophilised algal samples were sonicated in $1 \%$ acetic acid, filtered and analysed by HPLC according to the method described by Lawrence et al., (1995). Saxitoxins if present were oxidised using hydrogen peroxide and analysed using a Shimadzu LC10ADVp HPLC system with a Shimadzu RF10AXL flourescence detector set at an extinction wavelength of 330 nanometers and an emission wavelength of 390 nanometers. An Altima C18 column $(150 \mathrm{~mm} \times 4.6 \mathrm{~mm}, 5 \mu \mathrm{m})$ was used with a $1 \mathrm{ml}$ per minute linear gradient of $1 \%$ to $8 \%$ acetonitrile $/ 0.1 \mathrm{M}$ ammonium formate in 20 minutes. Saxitoxins if present were identified and quantified by comparison to standards obtained from NRC, Canada. A detection limit if $1 \mu \mathrm{g} \mathrm{L}^{-1}$ is easily achievable using this method.

The cylindrospermopsin content of Portuguese isolates of C. raciborskii was analysed using the method described by Eaglesham et al., (1999). Using a $150 \mu \mathrm{L}$ injection volume the 
limit of detection using this method is typically less than $0.2 \mu \mathrm{g} \mathrm{L}^{-1}$, with a linear response to at least $1000 \mu \mathrm{g} \mathrm{\textrm {L } ^ { - 1 }}$.

\section{RESULTS}

The four Portuguese isolates conformed to the species descriptions for C. raciborskii from natural populations by Baker (1991) and Komárek \& Kling (1991). All four isolates produced straight trichomes with slightly shorter and narrower vegetative cell and heterocyst dimensions compared with cultured isolates from northern Australia (Table 1; see also Saker $\&$ Neilan, 2001). Morphological data from the cultured isolates taken from Portugal and Australia were not compared statistically since they were grown in different culture media (Table 1). The presence of high concentrations of akinetes (resting spores) in cultures of the Portuguese isolates was a notable feature.

All mice provided with cell suspensions of $C$. raciborskii at doses ranging from $1337-1572$ $\mathrm{mg} \mathrm{kg}^{-1}$ exhibited symptoms of lethargy, piloerection and difficulty in breathing beginning ca. 20 minutes after administration. These symptoms continued with increasing severity until death, occurring between 8 and 24 hours after i.p administration. Mice dosed with $C$. raciborskii did not consume food or water after administration of the cell suspensions.
Mice provided with a suspension of A. falcatus and those administered with physiological saline appeared to be healthy and were necropsied after 24 hours.

The livers of mice administered with $C$. raciborskii cell suspensions (and also those administered with A. falcatus cell suspensions) were slightly enlarged in comparison to the mice administered with physiological saline, although there was no evidence of gross morphopathological effects on the liver such as paleness or widespread necrosis. The liver weight of these mice (expressed as a \% of body weight) were as follows; Odivelas Reservoir (PT1) (5.48 - 5.53 $\%$ ) (range of two individuals), Ardila River (PT2) $(4.88$ - $5.64 \%)$ Caia Reservoir (PT3) (5.21 - 5.72 \%), Maranhão Reservoir (PT4) (5.31 - $5.67 \%)$, A. falcatus control (5.22 - $5.30 \%)$ and physiological saline control (4.18 - 4.52\%).

Histological examination of liver tissues of mice administered with $C$. raciborskii cell suspensions showed hepatocellular necrosis and eosinophilic deposits, confined to the periphery of the organ (Fig. 2A). Hepatic cells adjacent to the necrotic area of the liver were swollen and showed cytoplasmatic damage and loss of nuclei (Fig. 2B). Towards the central region of the liver, hepatocytes showed no apparent damage (Fig. 2C). These effects were observed in both replicates of all four isolates. No abnormalities were observed in the livers of mice administered with A. falcatus or physiological saline alone.

Table 1. Morphological characteristics of four Portuguese and three Australian isolates of C. raciborskii grown in nitrogen-containing medium. Características morfológicas de cuatro aislados de C. raciborskii portugueses y tres australianos.

\begin{tabular}{lcccccc}
\hline Isolate & Source country & $\begin{array}{c}\text { Growth } \\
\text { media }\end{array}$ & $\begin{array}{c}\text { Cell length }(\mu \mathrm{m}) \\
\pm 1 \mathrm{SD}(\mathrm{N})\end{array}$ & $\begin{array}{c}\text { Cell width }(\mu \mathrm{m}) \\
\pm 1 \mathrm{SD}(\mathrm{N})\end{array}$ & $\begin{array}{c}\text { Heterocyst length } \\
(\mu \mathrm{m}) \pm 1 \mathrm{SD}(\mathrm{N})\end{array}$ & $\begin{array}{c}\text { Heterocyst width } \\
(\mu \mathrm{m}) \pm 1 \mathrm{SD}(\mathrm{N})\end{array}$ \\
\hline PT1 & Odivelas Reservoir, Portugal & $\mathrm{Z} 8$ & $5.70 \pm 1.79(53)$ & $2.35 \pm 0.26(53)$ & $6.98 \pm 1.03(36)$ & $2.91 \pm 0.26(36)$ \\
PT2 & Ardila River, Portugal & $\mathrm{Z} 8$ & $3.96 \pm 1.35(61)$ & $2.20 \pm 0.38(54)$ & $6.13 \pm 1.08(36)$ & $2.91 \pm 0.19(36)$ \\
PT3 & Caia Reservoir, Portugal & Z8 & $4.92 \pm 1.06(36)$ & $2.36 \pm 0.29(36)$ & $6.02 \pm 1.28(37)$ & $2.90 \pm 0.36(37)$ \\
PT4 & Maranhão Reservoir, Portugal & Z8 & $4.97 \pm 1.32(54)$ & $2.35 \pm 0.46(54)$ & $7.19 \pm 1.55(36)$ & $3.32 \pm 0.50(36)$ \\
$C R 2^{*}$ & Solomon Dam, Australia & ASM-1 & $5.24 \pm 1.21(35)$ & $3.57 \pm 0.42(35)$ & $10.31 \pm 1.54(35)$ & $3.79 \pm 0.36(35)$ \\
$C R 4^{*}$ & Goonyella Dam, Australia & ASM-1 & $4.67 \pm 1.10(38)$ & $2.66 \pm 0.24(38)$ & $8.33 \pm 1.87(38)$ & $3.82 \pm 0.58(38)$ \\
$C R 7^{*}$ & Lake Julius, Australia & ASM-1 & $5.66 \pm 1.03(35)$ & $2.90 \pm 0.18(35)$ & $9.26 \pm 1.53(35)$ & $3.79 \pm 0.36(35)$ \\
\hline
\end{tabular}

*Data from Saker and Neilan (2001) 


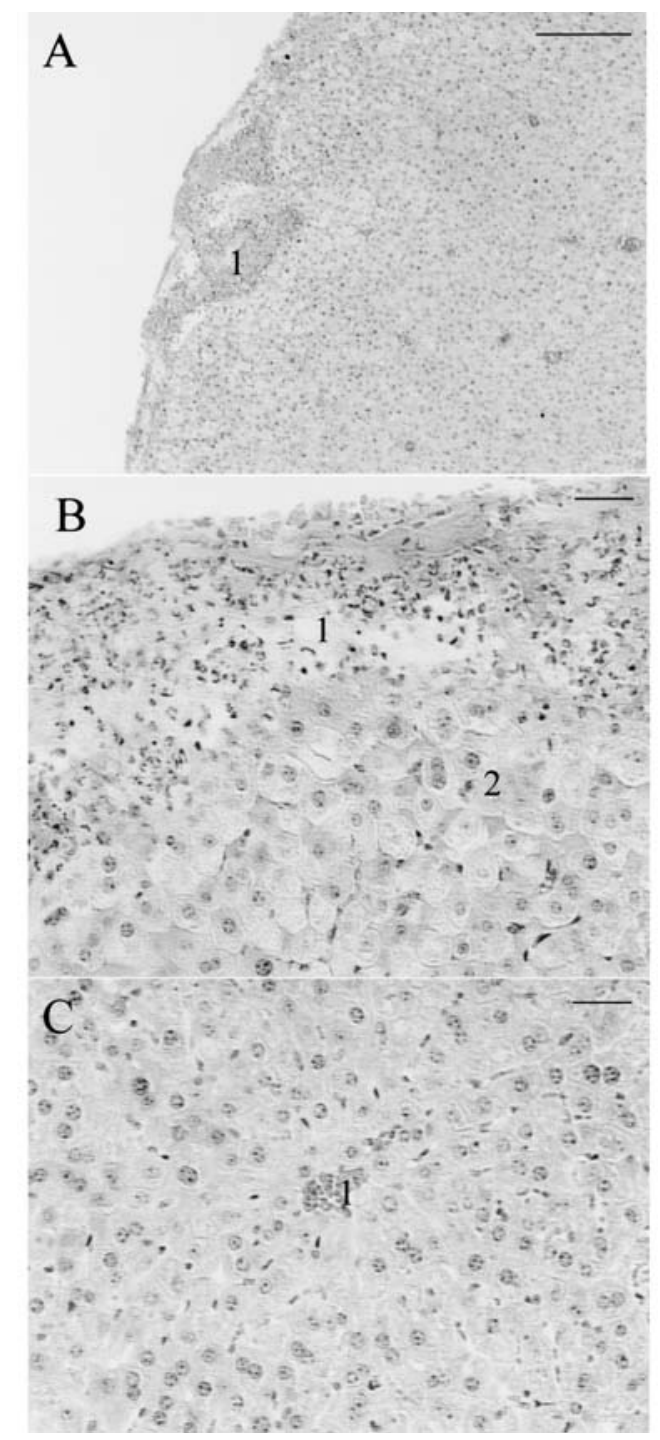

Figure 2. The liver of a mouse 24 hours after i.p. administration of C. raciborskii (1467 $\mathrm{mg} \mathrm{kg}^{-1}$ ) isolated from Ardila River (PT2). (A) Hepatocellular damage confined to the periphery of the organ (Scale bar $=200 \mu \mathrm{m})$. (B) Hepatocyte necrosis and eosinophilic material confined to the periphery of the liver (1). Cells adjacent to necrotic area showing alterations in cytoplasm, loss of nuclei and swelling (2). Scale bar $=40 \mu \mathrm{m}$ (C) Hepatocytes in central area of liver close to the central vein (1) showing no apparent damage. Scale bar $=40 \mu \mathrm{m}$. Higado de un ratón 24 horas después de la administración i. p. de C. raciborskii (1467 $\mathrm{mg} \mathrm{kg}^{-1}$ ) aislada del río Ardila (PT2). (A) daños hepatocelulares confinados en la periferia del órgano (barra de referencia $=200 \mu \mathrm{m})$. (B) necrosis de hepatocitos y material eosinofilico confinado a la periferia del hígado (1). Células adyacentes al área necrótica mostrando alteraciones del citoplasma, pérdida de núcleo e hinchadas (2). Barra de referencia $=40 \mu \mathrm{m} .(C)$ Hepatocitos del área central del hígado cercanos a la vena cedntral (1) sin mostrar daño aparente. Barra e referencia $=40 \mu \mathrm{m}$.
Histological examination of the intestine of mice provided with $C$. raciborskii cell suspensions also showed an enlargement of lymphatic follicles associated with the mucosa (Peyer's patches). No histological abnormalities were observed in the renal cortex, medulla or any other organs.

Cylindrospermopsin (or deoxy-cylindrospermopsin), microcystins and saxitoxins were not present at detectable concentrations in lyophilised biomass of any of the isolates.

\section{DISCUSSION}

C. raciborskii is a prominent component of the phytoplankton of many reservoirs and rivers in southern regions of Portugal. Whilst this report constitutes the first published record of this species in Portugal, a review of phytoplankton monitoring data from a range of government and private sources revealed ten water bodies where this species is seasonally abundant (Fig. 1). In Portuguese freshwaters, C. raciborskii has been detected at cell concentrations in excess of $3 \mathrm{x}$ $10^{6}$ cells $\mathrm{ml}^{-1}$ and as a co-dominant with other cyanobacteria, most notably Aphanizomenon, Merismopedia, and Oscillatoriales. Blooms of this species have been reported only during the warmer months from May to October and most reports of this species are from southern regions of Portugal $\left(<39^{\circ} \mathrm{N}\right)$ where summertime surface water temperatures can reach $>20^{\circ} \mathrm{C}$. This characteristic is in agreement with the reported growth temperature limit from this species (Saker \& Griffiths, 2000; 2001). All water bodies containing populations of $C$. raciborskii were characterised by temperatures ranging from 18.2 to $28.2^{\circ} \mathrm{C}, \mathrm{pH}$ values from 7.0-9.6 and $\mathrm{N}: \mathrm{P}$ ratios ranging from $4-25$.

Portuguese isolates were similar in morphology to those previously reported from Australian water bodies (Table 1) and all morphological measurements were within the ranges reported from other studies (Baker, 1991, Komárek \& Kling, 1991; Komárkova et al. 1999). The presence of high concentrations of 
akinetes in cultures of all four isolates was also a notable feature of the Portuguese C. raciborskii isolates since akinetes are rarely observed in cultures of this species from northern Australia. It is possible that $C$. raciborskii from temperate regions such as Portugal are better adapted to lower growth temperatures, where akinetes might be of greater importance for survival during the winter. In contrast, strains taken from tropical regions can persist in the vegetative form throughout the year and rarely produce akinetes in culture (Saker \& Griffiths, 2001).

Of main interest in this study was the observed toxic effects following i.p. administration of C. raciborskii cell suspensions to mice. As yet, the only toxins that have been reported to be produced by isolated strains of C. raciborskii are cylindrospermopsin (Hawkins et al. 1997; Saker et al., 1999a,b) and PSP's (Lagos et al., 1999). The toxic effects of the C. raciborskii cell suspensions as reported in this study could not be attributed to cylindrospermopsin or PSP toxins since HPLC/MS tests for these compounds were both negative. We furthermore tested cultured material for the presence of microcystins, a group of cyanoobacterial toxins produced by a range of freshwater cyanobacterial genera. HPLC analysis also confirmed an absence of microcystins.

The symptoms of poisoning in mice showed liver damage as the primary lesion, with some damage to the intestine. The effects of these cell extracts were quite different to those histological effects reported for cylindrospermopsincontaining cell extracts of $C$. raciborskii. There was no detectible swelling of the liver as has been reported for cylindrospermopsin intoxication (Hawkins et al., 1985, 1997; Seawright et al., 1999). Furthermore, hepatocyte damage was not centrilobular as has been reported for cylindrospermopsin (Hawkins et al., 1985, 1997). Instead, the primary lesion detected in this study was hepatocyte damage limited to the periphery of the liver (Fig. 2A) suggesting a different mode of toxin absorption. Also, unlike the work of Hawkins et al., $(1985 ; 1997)$ no damage to kidney, intestines or lungs was detected.
In a study by Neilan et al., (2003) investigating genetic variation in C. raciborskii strains taken from a range of global locations, it was found that $C$. raciborskii isolates from Europe are genetically distinguishable from $C$. raciborskii strains taken from other global locations (including Australia, Brazil and the USA) when analysed using HIP1 repeated sequence PCR. Interestingly, within the European group, strains of C. raciborskii isolated from Lake Balaton in Hungary are also known to have a toxic effect in the mouse bioassay (Törökné, pers. comm.). Due to the strong genetic similarity of strains from Portugal and Hungary based on results of the HIP1 PCR technique it is possible that strains of $C$. raciborskii from these two locations could share a similar toxic compound.

In this study, we were unable to determine the causative compound responsible for the hepatotoxic effects observed in the mouse bioassay. This study nevertheless highlights the need for a greater understanding of the range of toxic effects cyanobacteria can have and draws our attention to the increased need for monitoring of C. raciborskii in potable and recreational water bodies.

\section{ACKNOWLEDGEMENTS}

We would like to thank Joana Osswald (Faculdade de Ciências, Universidade do Porto) for technical assistance. This research was funded by grants from the EU CYANOTOX project and a PhD scholarship to Isabel Nogueira from the Fundação para a Ciência e a Tecnologia PRAXXIS XXI/BD/21757/99. We thank Begoña Fernández Durán for assistance with manuscript preparation.

\section{REFERENCES}

BAKER, P. D. 1991. Identification of common noxious cyanobacteria: Part I-Nostocales. Research Report No. 29, Urban Water Research Association of Australia, Melbourne.

BOURKE, A. T. C., R. B. HAWES, A. NEILSON \& N. D. STALLMAN. 1983. An outbreak of hepato- 
enteritis (the Palm Island mystery disease) possibly caused by algal intoxication. Toxicon, 3: 45-48.

BRIAND, J. F., C. ROBILLOT, C. QUIBLIERLLOBÉRAS, J. F. HUMBERT, A. COUTÉ \& C. BERNARD. Environmental context of Cylindrospermopsis raciborskii (Cyanobacteria) blooms in a shallow pond in France. Water Research, (in press).

BYTH, S. (1980). Palm Island mystery disease. Med. J. Aust., 2: 40-42.

COUTÉ, A., M. LEITAO \& C. MARTIN. 1997. Première observation du genre Cylindrospermopsis (Cyanophyceae, Nostocales) en France. Cryptogam. Algol., 18(1) : 57-70.

DOKULIL, M. T. \& J. MAYER. 1996. Population dynamics and photosynthetic rates of a Cylindrospermopsis - Limnothrix association in a highly eutrophic urban lake, Alte Donau, Austria. Algol. Stud., 83: 179-195.

EAGLESHAM, G. K., R. L. NORRIS, G. R. SHAW, M. J. SMITH, R. K. CHISWELL, B. C. DAVIS, G. R. NEVILLE, A. A. SEAWRIGHT \& M. R. MOORE. 1999. Use of HPLC-MS/MS to monitor cylindrospermopsin, a blue-green algal toxin, for public health purposes. Environ. Toxicol., 14(1): 151-155.

HAWKINS, P. R., N. R. CHANDRASENA, G. J. JONES, A. R. HUMPAGE \& I. R. FALCONER. 1997. Isolation and toxicity of Cylindrospermopsis raciborskii from an ornamental lake. Toxicon, 35: 341-346.

HAWKINS, P. R., M. T. C. RUNNEGAR, A. R. B. JACKSON \& I. R. FALCONER. 1985. Severe hepatotoxicity caused by the tropical cyanobacterium Cylindrospermopsis raciborskii (Woloszyńska) Seenaya and Subba Raju isolated from a domestic water supply reservoir. Appl. Environ. Microbiol., 50: 1292-1295.

HINDÁK, F. \& M. MOUSTAKA. 1988. Planktic cyanophytes of Lake Volvi, Greece. Arch. Hydrobiol. Suppl., 80 : 497-528.

HORECKÁ, M. \& J. KOMÁREK. 1979. Taxonomic position of three planktonic blue green algae from the genera Aphanizomenon and Cylindrospermopsis. Preslia, Praha, 51: 289-312.

KOMÁREK, J. \& H. KLING. 1991. Variation in six planktonic cyanophyte genera in Lake Victoria (East Africa). Arch. Hydrobiol., 88: 21-46.

KOMÁRKOVA, J., R. LAUDARES-SILVA \& P. A. C. SENNA. 1999. Extreme morphology of Cylindrospermopsis raciborskii (Nostocales,
Cyanobacteria) in the Lagoa do Peri, a freshwater coastal lagoon, Sabta Catarina, Brazil. Algol. Stud., 94, 207-222.

KOTAI, J. 1972. Instructions for preparation of modified nutrient solution Z8 for algae. Norgegian Institute for Water Research. B-11/69.

KRIENITZ, L. \& E. HEGEWALD. 1996. Uber das Vorkommen von warmellebenden blaualgenarten in einem norddeutschen. Lauterbornia, 26: 55-64.

LAGOS, N., H. ONODERA, P. A. ZAGATTO, D. ANDRINOLO, S. M. F. O. AZEVEDO \& Y. OSHIMA. 1999. The first evidence of paralytic shellfish toxins in the freshwater cyanobacterium Cylindrospermopsis raciborskii, isolated from Brazil. Toxicon, 37: 1359-1373.

LAWRENCE, J. F., C. MÉNARD \& C. CLEROUX. 1995. Evaluation of prechromatographic oxidation for liquid chromatographic determination of paralytic shellfish poisons in shellfish. J. Assoc. Off. Anal. Chem., 78: 514-520.

LI, R., W. W. CARMICHAEL, S. BRITTAIN, G. K. EAGLESHAM, G. R. SHAW, A. MAHAKHANT, N. NOPARATNARAPORN, W. YONGMANITCHAI, K. KAYA \& M. M. WATANABE. 2001. Isolation and identification of the cyanotoxin cylindrospermopsin and deoxy-cylindrospermopsin from a Thailand strain of Cylindrospermopsis raciborskii (Cyanobacteria). Toxicon, 39: 973-980.

NEILAN, B. A., M. L. SAKER, J. FASTNER, A. TÖRÖKNÉ \& B. P. BURNS. 2003. Phylogeography of the invasive cyanobacterium Cylindrospermopsis raciborskii. Mol. Ecol., 12: 133-140.

OHTANI, I., R. E. MOORE \& M. T. C. RUNNEGAR. 1992. Cylindrospermopsin: a potent hepatotoxin from the blue-green alga Cylindrospermopsis raciborskii. J. Amer. Chem. Soc., 114: 7942-7944.

PADISÁK, J. 1997. Cylindrospermopsis raciborskii (Woloszyńska) Seenaya et Subba Raju, an expanding, highly adaptive cyanobacterium: worldwide distribution and review of its ecology. Archiv Hydrobiol., 107: 563-593.

RESSOM, R., F. S. SOONG, J. FITZGERALD, L. TURCZYNOWICZ, O. E. SAADI, D. RODER, T. MAYNARD \& I. R. FALCONER. 1994. Health effects of toxic cyanobacteria. NHMRC. Australian Government Publishing, Australia.

ROMO, S. \& M. R. MIRACLE. 1994. Population dynamics and ecology of subdominant phytoplankton speciers in a shallow hypertrophic lake 
(Albufera of Valencia, Spain). Hydrobiologia, 273: 37-56.

SAKER, M. L. \& D. J. GRIFFITHS. 2000. The effect of temperature on growth and cylindrospermopsin content of seven isolates of the cyanobacterium Cylindrospermopsis raciborskii (Woloszynska) Seenayya and Subba Raju from water bodies in northern Australia. Phycologia, 39(4): 349-354.

SAKER, M. L. \& D. J. GRIFFITHS. 2001. Occurrence of blooms of the cyanobacterium Cylindrospermopsis raciborskii (Woloszynska) Seenayya and Subba Raju from a north Queensland domestic water supply. Mar. Freshwat. Res., 52(6): 907-915.

SAKER, M. L. \& B. A. NEILAN. 2001. Variable diazotrophies, morphologies, and toxicities of genetically similar isolates of Cylindrospermopsis raciborskii (Nostocales, Cyanophyceae) from northern Australia. Appl. Environ. Microbiol., 67(4): 1839-1945.

SAKER, M. L., B. A. NEILAN \& D. J. GRIFFITHS. 1999a. Two morphological forms of Cylindrospermopsis raciborskii (Cyanobacteria) isolated from Solomon Dam, Palm Island, Queensland. J. Phycol., 35: 599-606.

SAKER, M. L., A. D. THOMAS \& J. H. NORTON. 1999b. Cattle mortality attributed to the toxic cya- nobacterium Cylindrospermopsis raciborskii in an outback region of north Queensland. Environ. Toxicol., 14(1): 179-183.

SEAWRIGHT, A. A., C. C. NOLAN, G. R. SHAW, R. K. CHISWELL, R. L. NORRIS, M. R. MOORE \& M. J. SMITH. 1999. The oral toxicity for mice of the tropical cyanobacterium Cylindrospermopsis raciborskii (Woloszynka) Environ. Toxicol., 14: 135-142.

SHAW, G., A. SEAWRIGHT, M. SHAHIN, P. SENOGLES, J. MUELLER \& M. MOORE. 2000. The cyanobacterial toxin, cylindrospermopsin: Human health risk assesment. In Abstracts of the $9^{\text {th }}$ International Conference on Harmful Algal Blooms, Hobart. 7-11 February, Hobart, Tasmania.

SINGH, R. N. 1962. Seasonal variants of Anabaenopsis raciborskii Wolosz. Hydrobiologia, 20: 87-91.

THOMAS, A. D., M. L. SAKER, J. H. NORTON \& R. D. OLSEN. 1998. Cyanobacterium Cylindrospermopsis raciborskii as a probable cause of death in cattle in northern Queensland. Aust. Vet. J., 76: 592-594.

WOLOSZYŃSKA, J. 1912. Das phytoplankton einiger Javanian seen mit Berücksichtigung des sawaplanktons. Bull. Int. Acad. Sci. Cracoviae, Ser. B., 6: 649-709. 